\title{
Effects of Elevated Temperatures on the Properties of High Strength Cement Paste Containing Silica Fume
}

\author{
Nabil Abdelmelek ${ }^{1 *}$, Éva Lublóy ${ }^{1}$ \\ ${ }^{1}$ Department of Construction Materials and Technologies, Faculty of Civil Engineering, Budapest University of Technology and \\ Economics, Budapest 1521, Hungary \\ * Corresponding author, e-mail: abdelmelek.nabil@emk.bme.hu
}

Received: 18 November 2020, Accepted: 15 September 2021, Published online: 30 September 2021

\begin{abstract}
High strength concrete (HSC) production is worldwide increased and gradually replacing the normal strength concrete (NSC). The cement matrix of concrete is the essential part that governs the behavior and strength of concrete. Several researchers have focused on the performance of hardened cement paste (HCP) at ambient temperature such as using different types of supplementary cementitious materials (SCM). However, the performance of HCP after exposure to elevated temperatures requires further evaluation. The present study investigates the influence of different replacements of silica fume (SF) to cement and different water/binder ratios (w/b) on the compressive strength of HCP before and after exposure to elevated temperatures. Eighteen mixes have been prepared and tested. Results of compressive strength tests at ambient temperature were ranged from 58 to $102 \mathrm{MPa}$ depending on the difference of w/b. Furthermore, a new method has been adopted for comparing the responses of HCP at elevated temperatures "heat endurance". Results showed that using SF enhances the residual compressive strength of HCP after exposure to elevated temperatures due to the pozzolanic reaction and the filler contribution. Mixes containing $6 \%, 12 \%$, and $15 \%$ of SF have shown the highest relative residual compressive strength values for $0.30,0.35$, and $0.40 \mathrm{w} / \mathrm{b}$, respectively. Consequently, the results were significantly affected by changing the w/b ratio. Finally, different measurement techniques were provided to support the work, including Thermo-Gravimetric (TG), Computed Tomography (CT), and Scanning Electron Microscope (SEM) analysis to characterize the loss of mass, porosity, and microstructure alteration of HCP.
\end{abstract}

\section{Keywords}

silica fume, elevated temperatures, hardened cement paste, water to binder ratio, supplementary cementitious materials

\section{Introduction}

Since the 1950s, high-strength concrete (HSC) is widely produced as a proper substitute material for conventional concrete. The use of low water/binder ratio (w/b) and high content of cementitious materials are necessary for the production of HSC [1]. Using supplementary cementitious materials (SCM) such as silica fume (SF) and fly ash (FA) as partial replacements to ordinary Portland cement (OPC) have been found to satisfy several economic, environmental, and performance values [2].

Silica fume is a by-product material produced from elemental ferrosilicon alloys with about $30 \%$ of mass-produced silicon. SF is a very fine non-crystalline silica powder produced as secondary material that moves out from the furnaces [3]. SF has a high content of amorphous silicon dioxide $\left(\mathrm{SiO}_{2}\right)$, more than $90 \%$ of its chemical compositions, and ultrafine spherical particles with a typical average diameter of 0.1 to $0.2 \mu \mathrm{m}$ for the particle [4]. In addition to the physical properties, the color of SF is varied from light to dark gray, that is mainly due to the carbon and iron oxides. ACI Committee 234 statistics states that around 900,000 metric tons $(1,000,000$ tons) of SF are produced annually in the world [4]. Therefore, many advantages have made SF the most well-known SCM in the recent years [5]. The chemical and physical properties of SF are the main reasons for the high pozzolanic activity with Portland cement [6-7]. Cohen et al. [8] reported that the diameter average of the individual particles of SF is less than $0.1 \mu \mathrm{m}$ that about 100 times smaller than of OPC particles. Thus, it is foreseeable that SF has a pronounced effect in the concrete properties.

The first studies that used SF in concrete were started in the 1950s [4]. Wang et al. [9] concluded that replacing cement with $2 \%$ to $5 \%$ of SF producing a dense structure 
with a consequent increase the fracture toughness and enhance the microhardness. The increase in the mechanical properties is obtained by the densification of the microstructure and the formation of calcium silicate hydrates (C-S-H) that ultimately help to develop the strength [10]. The advantages of SF are not limited to ambient temperatures, but it also changes the behavior of concrete properties after exposure to elevated temperatures. Several studies have been carried out to evaluate the performance of HSC containing SF after exposure to elevated temperatures [11-13]. Phan and Carino [14] have investigated the mechanical properties of HSC exposed to elevated temperatures up to $600{ }^{\circ} \mathrm{C}$. The experimental parameters were SF replacements using $0 \%$ and $10 \%$, and different $\mathrm{w} / \mathrm{b}$ ratios, i.e., $0.22,0.33$, and 0.57 . Results indicated that the loss in the residual strength was affected by the amount of $w / b$ ratio, showing an increase in the probability of spalling as the $\mathrm{w} / \mathrm{b}$ ratio decrease. In the results there was no clear evidence that the presence of SF by itself affect the tendency of explosive spalling. The advantages of SF are restricted by the sudden occurrence of spalling that corresponds to the heat pressure and the dense pore structure. Hertz [15] studied the effect of different SF replacements to cement i.e., $0 \%, 5 \%, 10 \%$, and $15 \%$ on the behavior of concrete at elevated temperatures. The authors suggested that $10 \%$ of SF replacements is the upper limit to avoid spalling of concrete. Poon et al. [11] investigated the behavior of HSC prepared with SF and at $0.3 \mathrm{w} / \mathrm{b}$ ratio after exposure to elevated temperatures. Results showed poor performance, especially above $10 \%$ of SF replacement to cement. Behnood and Ziari [5] investigated the effect of different replacements of SF to cement and different $w / b$ ratio on the residual compressive strength of HSC after exposure to elevated temperatures. They concluded that the replacements of SF have shown a negligible effect on the relative residual compressive strength at $100{ }^{\circ} \mathrm{C}$ and $200{ }^{\circ} \mathrm{C}$. However, the contribution of SF has shown a considerable influence on the residual compressive strength when temperature is elevated above $300{ }^{\circ} \mathrm{C}$. The optimum replacement of SF was found to be at $6 \%$ replacement to cement.

The main objective of the abovementioned studies was to evaluate the potential resistance of HSC containing $\mathrm{SF}$ against spalling. In conclusion, $\mathrm{HSC}$ is more prone to spalling than normal strength concrete (NSC) at elevated temperatures, declaring that the high density of HSC is the main reason for spalling [16].

The evaluation of the problem requires further studies. Previous reports $[17,18]$ have shown that the thermal decomposition of hardened cement paste (HCP), thermal gradients, pore-structure coarsening, and structure micro- cracking are the main types of deterioration of concrete at elevated temperatures. Due to the fact that the bonding potential of concrete depends mainly upon the cement paste matrix, any damage of the HCP results in a decline in the bond and the properties of concrete. Therefore, the effect of elevated temperatures on the micro and macrostructure levels of HCP is of great interest in terms of evaluating the overall behavior of HSC [19]. A few numbers of research have been carried out on HCP containing SCM subjected to elevated temperature. With respect to the cement paste mixes, Heikal et al. [20] studied the HCP containing different $\mathrm{SF}$ replacements to cement i.e., $0 \%, 5 \%, 10 \%, 15 \%$, and $20 \%$. They concluded that the compressive strength of the mixtures containing $10 \%, 15 \%$ of SF have shown high resistance to elevated temperatures. Gómez-Zamorano and Escalante-García [21] have reported that the increase in temperature is highly accelerating the pozzolanic reaction.

Finally, the process of testing and evaluating of the microstructure of HCP is complex due to many factors such as the shape and fineness of cement particles, grading of particles, oxide compositions, and $\mathrm{w} / \mathrm{b}$ ratio. The finding of this experimental work ultimately provides a resistive HCP against elevated temperature for mitigating the damage of buildings under elevated temperatures. The compressive strength is the test that used for the examination of mechanical property of the HCP. The results are also supported by other measurements such as (i) loss of mass that was investigated using Thermogravimetric (TG) tests, (ii) Investigation of porosity and pore distribution that was conducted using Computed Tomography (CT), and (iii) Scanning Electron Microscope images which were captured to provide reliable evaluation of the HCP microstructure.

\section{Experimental work \\ 2.1 Materials}

Six groups of cement paste mixtures blended with SF were mixed and prepared using different incremental replacements i.e., $0 \%, 3 \%, 6 \%, 9 \%, 12 \%$, and $15 \%$ to cement weight and tested at three different $\mathrm{w} / \mathrm{b}$ ratios $(0.30,0.35$, and 0.40). Determining the optimum replacement of SF for each $w / b$ ratio is of great importance for the performance of HCP. Otherwise, the application of SF over the optimum replacement may reduce the mechanical and durability properties of the HCP. The total number of the mixes were eighteen, each mixture contains 24 cubes derived from eight different temperatures $(20,50,150,300,400,500$, 800 and $900^{\circ} \mathrm{C}$ ). The detailed parameters of eighteen mixtures are shown in Table 1. 
Table 1 Experimental matrix with detailed parameters

\begin{tabular}{|c|c|c|c|c|c|c|c|c|c|c|c|}
\hline \multicolumn{12}{|c|}{ Mixture proportion in $\mathrm{kg} / \mathrm{m}^{3}$} \\
\hline \multicolumn{4}{|c|}{$\mathrm{w} / \mathrm{b}=0.30$} & \multicolumn{4}{|c|}{$\mathrm{w} / \mathrm{b}=0.35$} & \multicolumn{4}{|c|}{$\mathrm{w} / \mathrm{b}=0.40$} \\
\hline Mix & SF & CEM I & Water & Mix & SF & CEM I & Water & Mix & SF & CEM I & Water \\
\hline SF 0\% & 0 & 480 & 144 & SF $0 \%$ & 0 & 480 & 168 & SF 0\% & 0 & 480 & 192 \\
\hline SF $3 \%$ & 14.4 & 465.6 & 144 & SF $3 \%$ & 14.4 & 465.6 & 168 & SF $3 \%$ & 14.4 & 465.6 & 192 \\
\hline SF $6 \%$ & 28.8 & 451.2 & 144 & SF $6 \%$ & 28.8 & 451.2 & 168 & SF $6 \%$ & 28.8 & 451.2 & 192 \\
\hline SF $9 \%$ & 43.2 & 436.8 & 144 & SF 9\% & 43.2 & 436.8 & 168 & SF 9\% & 43.2 & 436.8 & 192 \\
\hline SF $12 \%$ & 57.6 & 422.4 & 144 & SF $12 \%$ & 57.6 & 422.4 & 168 & SF $12 \%$ & 57.6 & 422.4 & 192 \\
\hline SF $15 \%$ & 72 & 408 & 144 & SF $15 \%$ & 72 & 408 & 168 & SF $15 \%$ & 72 & 408 & 192 \\
\hline
\end{tabular}

The materials used in this experimental program are OPC and SF, which are supplied by a Hungarian company (Duna Drava company), and Sika Hungária company. The physical and chemical properties of cement and SF corresponds with the European standards, as shown in Table 2 [22]. CEM I $42.5 \mathrm{~N}$ is used within the specification of European standard [23]. The CEM I $42.5 \mathrm{~N}$ constitutes mainly $\mathrm{CaO}$, $\mathrm{SiO}_{2}$, and $\mathrm{Al}_{2} \mathrm{O}_{3}$. However, the crystalline phases could be defined as $3 \mathrm{CaO} \cdot \mathrm{SiO}_{2}\left(\mathrm{C}_{3} \mathrm{~S}\right.$, alite, hatrurite $)$ as the main crystalline component; $2 \mathrm{CaO} \cdot \mathrm{SiO}_{2}\left(\mathrm{C}_{2} \mathrm{~S}\right.$, belite, larnite); $\mathrm{CaSO}_{4} \cdot 2 \mathrm{H}_{2} \mathrm{O}\left(\mathrm{CSH}_{2}\right.$, gypsum); $3 \mathrm{CaO} \cdot \mathrm{Al}_{2} \mathrm{O}_{3}\left(\mathrm{C}_{3} \mathrm{~A}\right.$, tricalcium aluminate); and $4 \mathrm{CaO} \cdot \mathrm{Al}_{2} \mathrm{O}_{3} \cdot \mathrm{Fe}_{2} \mathrm{O}_{3}\left(\mathrm{C}_{4} \mathrm{AF}\right.$, brownmillerite), as shown in Table 3. Fig. 1 shows the sieve curve for the grading of cement particles. The used SF is entirely amorphous, and has a particle diameter of less than $1 \mu \mathrm{m}$, while the sieve refusal $>45 \mu \mathrm{m}$ is $2 \%$.

The water used for mixing is tap water, which complies with the standard requirements of EN 1008:2002 [24].

\subsection{Mixing procedures}

Mixing was carried out in accordance with EN 196-1 at room temperature $\left(20 \pm 2{ }^{\circ} \mathrm{C}\right)$ [25]. At the beginning, a dry mix of cement and SF has been carried out for 30 seconds to homogenize the binder. Then for two minutes, mixing of the binder and water has been carried out. To avoid the agglomeration of unhydrated particles, the total amount of water was mixed with $75 \%$ of the binder, after that, the remaining amount was added during the mixing. The cement paste was cast in cubes $(30 \times 30 \mathrm{~mm})$. A vibrating table was used to remove air bubbles from the fresh mix. The casted cubes were placed for 24 hours in lab condition $\left(20 \pm 2^{\circ} \mathrm{C}\right)$ until de-moulding. After that, cubes were cured for seven days in a water tank then stored in the lab. According to the Concrete Society Ltd., London (United Kingdom), the use of SF requires at least seven days of water curing [26].
Table 2 Chemical composition and physical characteristics of cement and SF

\begin{tabular}{|c|c|c|}
\hline Measured property & CEM I $42.5 \mathrm{~N}$ & SF \\
\hline Density $\left(\mathrm{g} / \mathrm{cm}^{3}\right)$ & 3.13 & 2.20 \\
\hline Specific surface area $\left(\mathrm{cm}^{2} / \mathrm{g}\right)$ & 4000 & 20000 \\
\hline \multicolumn{3}{|c|}{ Oxide compositions (\%) (by mass) } \\
\hline $\mathrm{SiO}_{2}$ & 19.84 & 96.43 \\
\hline $\mathrm{Al}_{2} \mathrm{O}_{3}$ & 5.38 & 0.00 \\
\hline $\mathrm{Fe}_{2} \mathrm{O}_{3}$ & 3.22 & 0.07 \\
\hline $\mathrm{Ca} 0$ & 64.90 & 0.78 \\
\hline $\mathrm{Mg} 0$ & 1.38 & 0.70 \\
\hline $\mathrm{SO}_{3}$ & 2.97 & 0.04 \\
\hline $\mathrm{K}_{2} 0$ & 0.78 & 1.28 \\
\hline $\mathrm{K}_{2} \mathrm{SO}_{4}$ & 0.02 & 0.00 \\
\hline $\mathrm{MgO}$ & 0.25 & 0.00 \\
\hline Loss on ignition $(\%)$ & 3.00 & 2.80 \\
\hline
\end{tabular}

\begin{tabular}{lc}
\multicolumn{2}{c}{ Table 3 Phase compositions of cement } \\
\hline Phase Compositions of CEM I 42.5 & Mass (\%) \\
\hline $\mathrm{C}_{3} \mathrm{~S}$ & 69.4 \\
$\mathrm{C}_{2} \mathrm{~S}$ & 14.3 \\
$\mathrm{C}_{3} \mathrm{~A}$ & 4.9 \\
$\mathrm{C}_{4} \mathrm{AF}$ & 9.83 \\
\hline
\end{tabular}

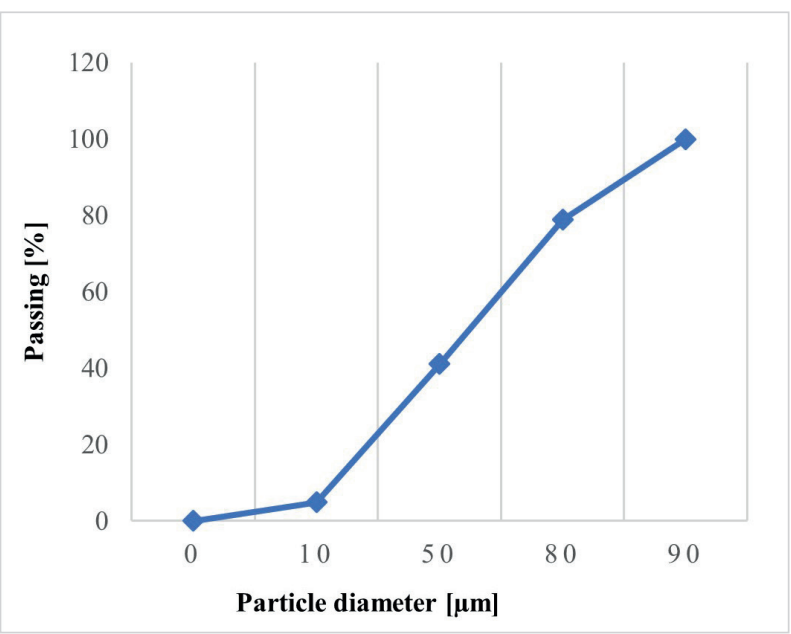

Fig. 1 Grading curve of cement 


\subsection{Testing and heating procedure}

Mixtures of HCP were tested in both fresh and hardened phases. For the fresh property, a Haegermann-Flow Table was used; it contains an aluminum/glass plate with a diameter of $\varnothing 300 \mathrm{~mm}$ and funnel cone $\varnothing 70 / 100 \mathrm{~mm}$. During the test, the funnel should be placed in the center of the table. The funnel was filled in two layers; each layer has been tamped 10 times with a tamper. Then, only after 15 seconds, we removed the funnel. Finally, the table is jolted 15 times with a rate of 1 jolt per second, and the diameter is measured in two directions. The test is conformed to DIN EN 459-2 standard [27].

In hardened properties, a compressive strength test was conducted on HCP specimens with a loading rate of $1.40 \mathrm{kN}$. The test is carried out by ALPHA 3/3000S test machine with a capacity of $200 \mathrm{kN}$ for compressive stress. The test method and heating program have been applied as follow:

At the age of 90 days, tests were conducted. The heating program was applied for every set of three cubes; the temperature is logarithmically (according to the ISO 834 [28]) increased up to the target temperature level then fixed for two hours. Different temperature levels were applied: 20, $50,150,300,400,500,800$, and $900{ }^{\circ} \mathrm{C}$, then the specimens were naturally cold down. The temperature range used in this study is similar to that which could occur in a real fire situation [28]. The selection of the temperature ranges was based on the chemical reaction and physical changes of the HCP. At the relatively high temperature, i.e., $50{ }^{\circ} \mathrm{C}$ and $150^{\circ} \mathrm{C}$, there was a transient decrease in strength, therefore, $50{ }^{\circ} \mathrm{C}$ and $150{ }^{\circ} \mathrm{C}$ were chosen to test the rate of decrease. Decomposition of Portlandite occurs between $400{ }^{\circ} \mathrm{C}$ and $500{ }^{\circ} \mathrm{C}$. Then, after $800{ }^{\circ} \mathrm{C}$ heat load, decomposition of $\mathrm{CSH}$ certainly occurs, taking into account the measurement error of the furnaces. The temperature load of $900{ }^{\circ} \mathrm{C}$ was used to examine the tendency of the decrease of strength changes due to the additional heat load.

\subsection{Thermogravimetric (TG) analysis}

Thermogravimetric investigation defines various thermal decompositions of different HCP products and phases with simultaneous estimation of the mass loss in static conditions. Besides, changes in phases were controlled by Thermogravimetry/Derivative Thermogravimetry/ Differential Thermal Analysis (TG/DTG/DTA) and MOM Derivatograph-Q 1500 D TG/DTA instruments. During the measurements, $\mathrm{Al}_{2} \mathrm{O}_{3}$ is the reference material where the mass of the sample is $300 \mathrm{mg}$. The heating rate of samples was $10^{\circ} \mathrm{C} \min ^{-1}$ up to $1000{ }^{\circ} \mathrm{C}$ in the air atmosphere. The samples for thermogravimetric were ground to fine powder measured in TG/DTA to ensure samples' soundness from carbonation, the powders were selected from the core of specimens. The thermo-analytical test results were determined by Winder (Version 4.4.) software. The tested powders were taken from specimens of ambient temperatures $\left(20^{\circ} \mathrm{C}\right)$. The investigated powders were for the reference mixture (SF 0\%), and the mixture containing the optimum replacement of SF obtained at elevated temperature for the mixture prepared with $0.30 \mathrm{w} / \mathrm{b}$ ratio. The TG/DTA studies were carried out when the samples reached 90 days of age.

\subsection{Computed Tomography}

The examination of permeability, pores, and pore size distribution of HCP is feasible using CT method [29]. Siemens Somatom 16 was used for the CT tests at the Diagnostic and Oncoradiology Institute of Kaposvar University in Hungary. The thickness of the slices was $1.5 \mathrm{~mm}$ while the pixel spacing was $0.225 \mathrm{~mm}$. The samples were unloaded during the CT analyses. The CT slices were processed by automated algorithms in Matlab environment using predefined parameters without any user interaction [30]. CT measurements have been carried on cylindrical specimens with a diameter of $100 \mathrm{~mm}$ and a height of $50 \mathrm{~mm}$ for reference and SF mixtures. The test results with CT intended to demonstrate porosity and pore distributions through HCP with and without SF. The pores content was determined as the sum values of slices that were taken along the sample's vertical axis.

\subsection{Scanning electron microscope}

Scanning electron microscope was used to examine the microstructure of HCP using Phenom XL SEM in the lab of Budapest university of Technology and Economics. SEM offers great magnification and resolution to the microstructural level of the modified HCP [31]. The tested samples were prepared with a smooth viewing face in order to obtain a better image resolution. SEM images were taken for both reference sample (SF 0\%) and samples containing SF. After the compressive strength test, the samples have been selected from the core of the cross-sectional areas of the specimen. Then, the samples faces were coated with golden spray for a duration of 30 second, then the samples were investigated using SEM. 


\section{Results and discussion}

\subsection{Fresh property}

SF improves the physical properties of the cement paste matrix by reducing the bleeding. As a result, nucleation sites are provided, where the hydration products can readily precipitate. Table 4 shows the results of the slump test illustrating that the presence of SF material is not significantly affecting the degree of slump for a given cement matrix mixture. However, the paste mixtures containing SF showed more cohesion than ordinary cement paste and slightly harsh as far as the SF content was increased, particularly for mixes of low $\mathrm{w} / \mathrm{b}$ ratio.

\subsection{Results at ambient temperature}

\subsubsection{Compressive Strength}

All results of compressive strength were tested at the specimens of 90 days of age. The compressive strength values of eighteen mixtures before heating are presented in Fig. 2. The standard deviation for each value was calculated and presented in the form of error bar, showing the consistency of compressive strength values. HCP mixtures containing the following SF replacements of $9 \%, 9 \%$, and $6 \%$ for the $\mathrm{w} / \mathrm{b}$ ratios of $0.30,0.35$, and 0.40 , respectively, have shown the highest compressive strength values. This resulted in compressive strength values reaching 101.88 MPa, 99.81 MPa, and 87.73 MPa, respectively. This improvement in compressive strength is mainly associated with the reaction of the hydration product of cement with $\mathrm{SF}$ forming $\mathrm{C}-\mathrm{S}-\mathrm{H}$, along with the filler role of SF particles [5]. Considerable differences were recorded in the compressive strengths due to the changing in the $\mathrm{w} / \mathrm{b}$ ratio, as shown in Fig. 2.

Furthermore, specimens containing the optimum replacements of SF showed higher increase of compressive strength values than the values of its reference specimens (SF 0\%). The gain of compressive strength value based on SF replacements increased up to $9 \%$ replacement for all mixtures of $\mathrm{w} / \mathrm{b}$ ratios of $0.30,0.35$ and 0.40 .

\subsection{Results after the exposure to elevated temperature}

The results of residual compressive strength after the exposure to elevated temperature are presented in this subsection. The specimens were tested at the 90 days of age, that recommended by RILEM (Réunion Internationale des Laboratoires et Experts des Matériaux) [32]. As a function of the temperature, the relative residual compressive strength results were calculated by the ratio of the residual compressive strength of each temperature level to the
Table 4 Slump test results $(\mathrm{mm})$

\begin{tabular}{lll}
\hline SF replacement level & $0 \%$ & $15 \%$ \\
\hline $0.3 \mathrm{w} / \mathrm{b}$ & 220 & 190 \\
$0.35 \mathrm{w} / \mathrm{b}$ & 260 & 250 \\
$0.4 \mathrm{w} / \mathrm{b}$ & 300 & 300 \\
\hline
\end{tabular}

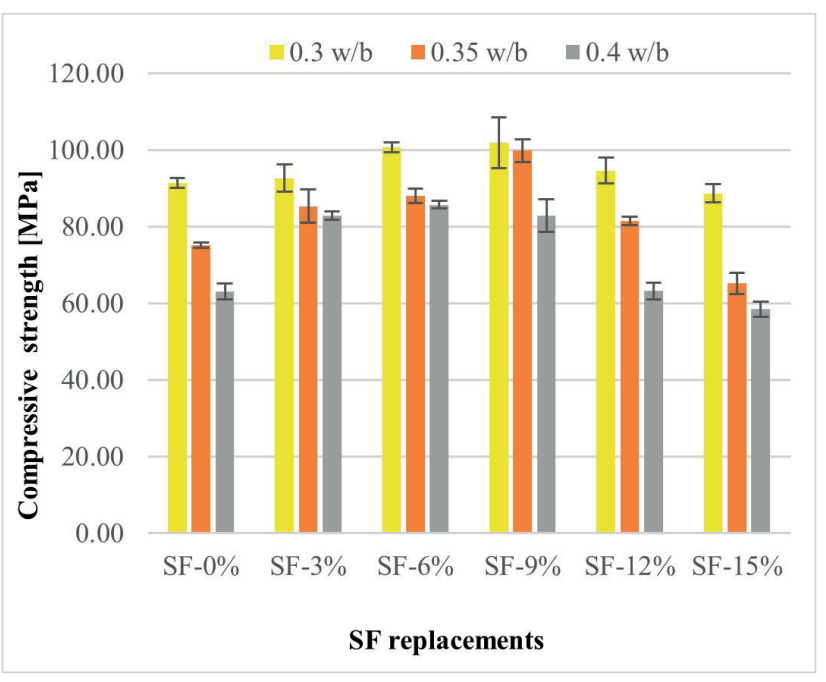

Fig. 2 Compressive strength results

same mixture's compressive strength at ambient temperature. The compressive strength of each mixture at ambient temperatures is presented in Fig. 2. In addition to the detailed results of the curves, the heat endurance method could also be used in this study by calculating the area under each curve [33].

\subsubsection{Effect of SF amounts}

The results of the relative residual compressive strength of HCP prepared with different SF replacements and w/b ratios after heating to different temperatures are presented in Figs. 3, 4, and 5. Heat endurance has been calculated and presented in Figs. 6, 7, and 8 as well. Generally, the relative residual strength decreases after temperature exposure up to $150{ }^{\circ} \mathrm{C}$, because of the dehydration of cement product (decomposition of ettringite). Then the residual strength increases up to $300^{\circ} \mathrm{C}$, because of the hydration of the un-hydrated cement grains in the microstructure due to steam movement. Afterward (more than $300^{\circ} \mathrm{C}$ ), the residual strength decreases again (as shown in the Figs. 3-5). This result was reported by previous studies as well [34].

Figs. 3-5, show that improvement in the strength of SF mixtures is occurred with the increase of temperatures, especially after $150{ }^{\circ} \mathrm{C}$. This increase could be attributed to the fact that SF mixtures are enriched with fine particles in which the hydration of un-hydrated particles is more 
compared to the ordinary mixture. Subsequently, with an increase of temperature up to $500{ }^{\circ} \mathrm{C}$, significant reductions occurred in the relative residual compressive strength of the reference mixtures (SF 0\%) mainly due to the decomposition of portlandite $(\mathrm{Ca}(\mathrm{OH}) 2)$. As shown in Figs. 3-5, the relative residual strength reaches $24 \%, 34 \%$, and $40 \%$ at $500{ }^{\circ} \mathrm{C}$ for $0.30,0.35,0.40 \mathrm{w} / \mathrm{b}$ ratio, respectively. On the other hand, the relative residual strength increases in the presence of SF. For specimens prepared using $w / b$ ratio of 0.30 , the relative residual compressive strength values of specimens containing $6 \%$ and $9 \%$ of SF were $97 \%$ and $92 \%$ after heating to $500{ }^{\circ} \mathrm{C}$ of ambient-temperature strengths,

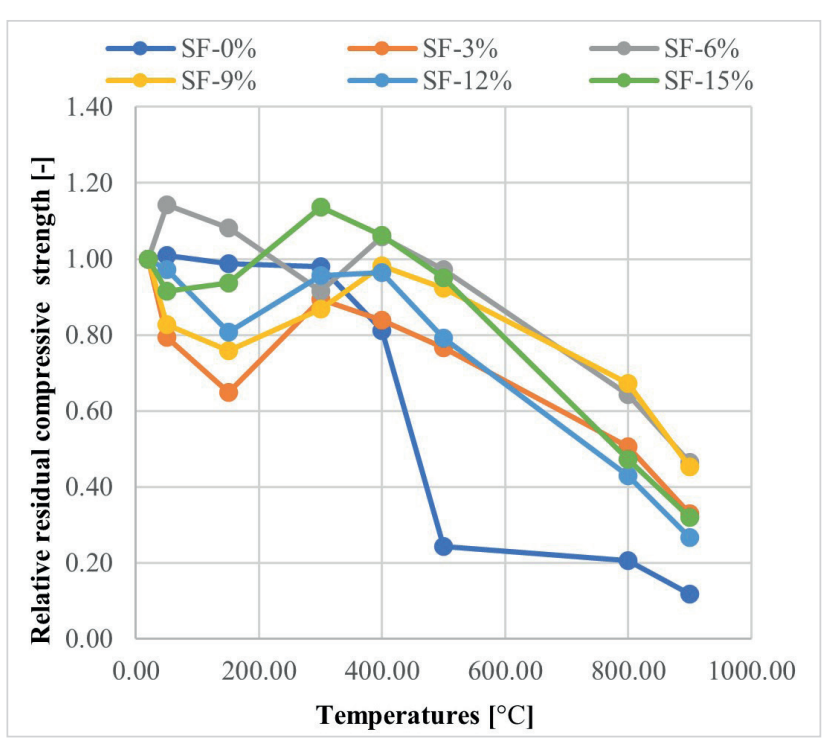

Fig. 3 Relative residual compressive strength of HCP as a function of temperature and SF replacements for $0.30 \mathrm{w} / \mathrm{b}$

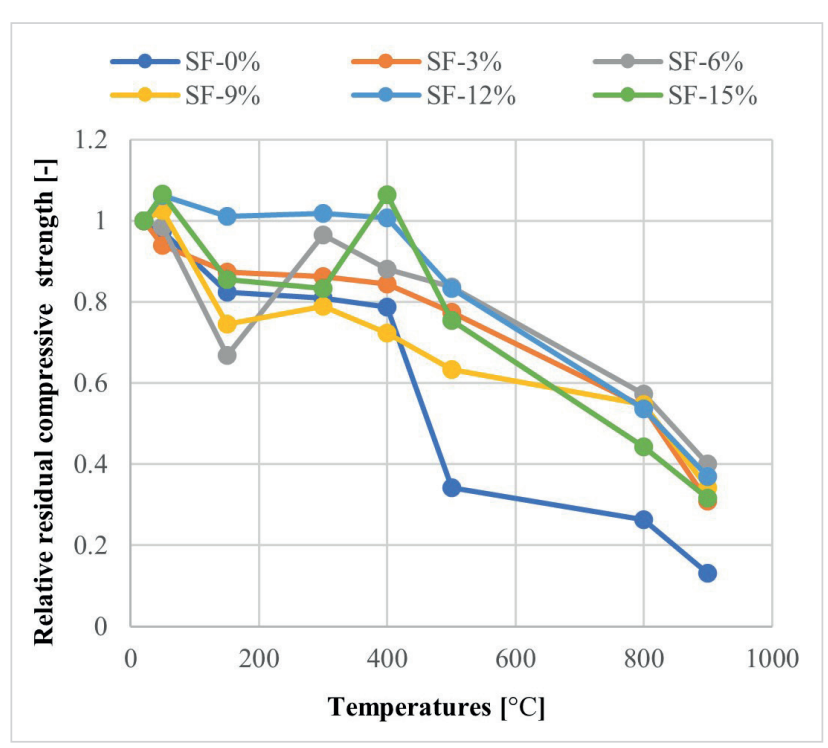

Fig. 4 Relative residual compressive strength of HCP as a function of temperature and SF replacements for $0.35 \mathrm{w} / \mathrm{b}$ respectively. Test results showed that the relative residual strength values decreased up to $64 \%$ and $67 \%$ for $6 \%$ and $9 \%$ of SF replacement, respectively after heating to $800{ }^{\circ} \mathrm{C}$ as shown in Fig. 3. Moreover, using more than $9 \%$ replacement of SF, the relative strength decreases at elevated temperature which could be due to the dense microstructure [11]. Fig. 4 shows that the presence of SF enhances the heat endurance of all the paste mixtures for $0.30 \mathrm{w} / \mathrm{b}$. Therefore, $6 \%$ of SF presents the highest heat endurance value that could be accepted as an optimum replacement.

Results of HCP mixtures made by w/b ratio of 0.35 are presented in Fig. 5. Results show that relative residual strength values of specimens contain $12 \%$ of SF were $84 \%$ and $53 \%$ after heating to $500{ }^{\circ} \mathrm{C}$ and $800{ }^{\circ} \mathrm{C}$, respectively. As illustrated in Fig. 7, the heat endurance was increased with the incorporation of SF, whereas mixture with $12 \%$ of SF showed the highest heat endurance.

Fig. 5 shows the relative residual strength results of specimens prepared with $0.40 \mathrm{w} / \mathrm{b}$ ratio. The mixture containing $15 \%$ of SF showed the highest relative residual strength values. The relative strength values were $77 \%$ and $51 \%$ after heating to $500{ }^{\circ} \mathrm{C}$ and $800{ }^{\circ} \mathrm{C}$, respectively. The heat endurance results presented the performance advantage of using mixtures containing 15\% of SF, as shown in Fig. 8.

In terms of the test results, the positive contribution of SF is significant, especially in case of mixtures containing the optimum replacements of SF obtained in the three $\mathrm{w} / \mathrm{b}$ ratios. The ultra-fine particles of SF that contribute as excellent fillers and their pozzolanic reactions lead to the formation of a very dense microstructure in the HCP,

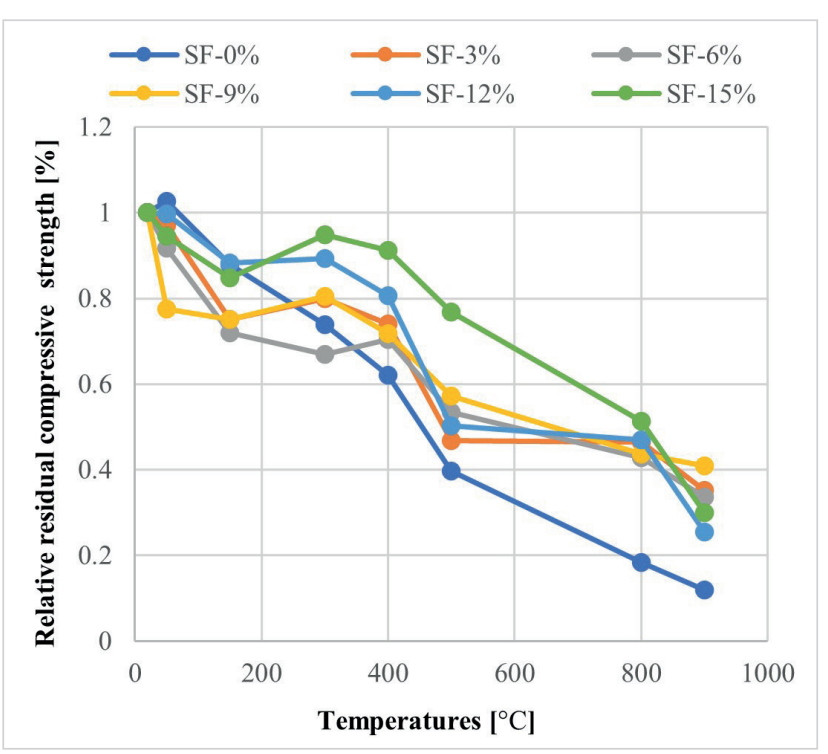

Fig. 5 Relative residual compressive strength of HCP as a function of temperature and SF replacements for $0.40 \mathrm{w} / \mathrm{b}$ 
resulting an $\mathrm{HCP}$ with a high capacity to resist elevated temperatures. Above $400{ }^{\circ} \mathrm{C}$, the efficiency of SF in the HCP was increased significantly, this could be interpreted by decreasing the effect of decomposition of $\left(\mathrm{Ca}(\mathrm{OH})_{2}\right)$ by pozzolanic reaction [34].

\subsubsection{Effect of $w / b$ ratio}

The effect of changing the $\mathrm{w} / \mathrm{b}$ ratio on the residual compressive strength of HCP after the exposure to elevated temperatures is plotted in Fig. 9. The results could be divided into two groups, based on the changes in the behavior during the exposure to elevated temperatures. The first

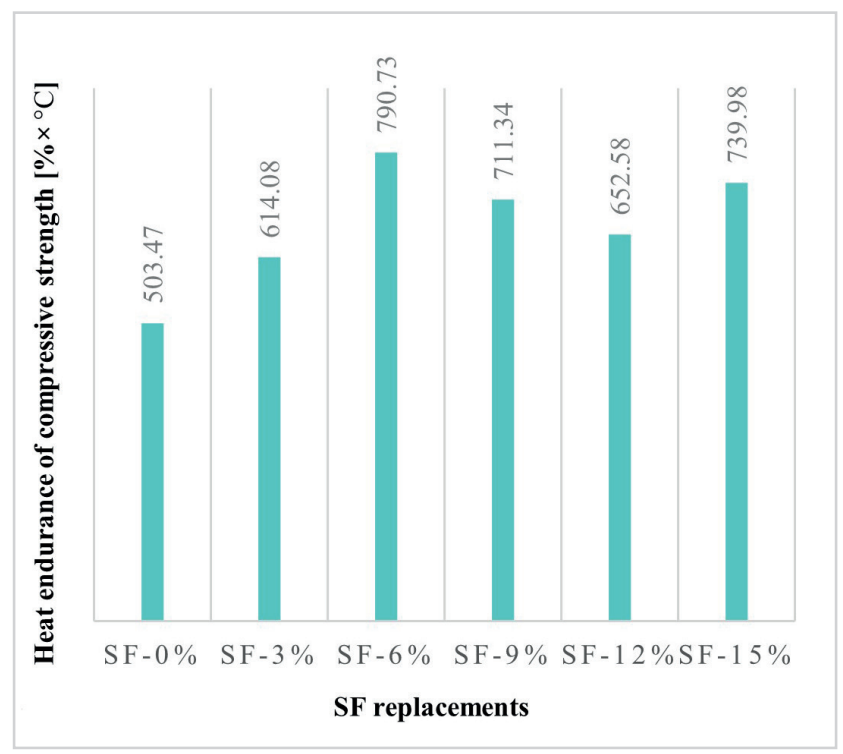

Fig. 6 Heat endurance of all HCP mixtures prepared with $0.30 \mathrm{w} / \mathrm{b}\left[\% \times{ }^{\circ} \mathrm{C}\right]$

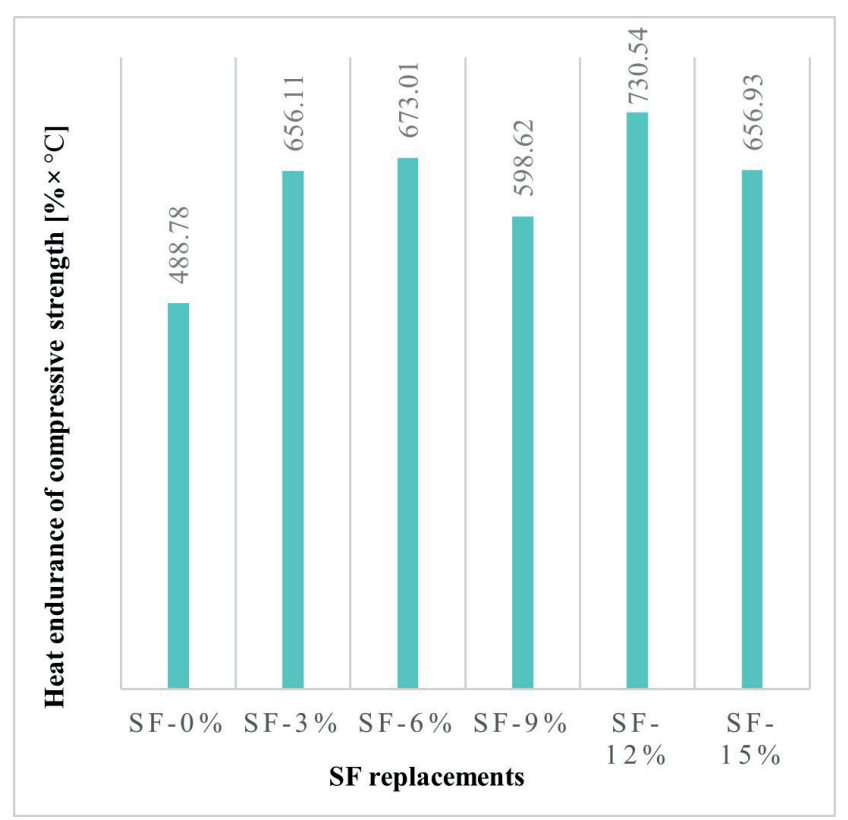

Fig. 7 Heat endurance of all $\mathrm{HCP}$ mixtures prepared with $0.35 \mathrm{w} / \mathrm{b}\left[\% \times{ }^{\circ} \mathrm{C}\right]$ group is the results of the relative residual strength in the range of 20 to $400{ }^{\circ} \mathrm{C}$, while the second group is the results obtained after $400{ }^{\circ} \mathrm{C}$. As illustrated in Fig. 9, the specimens prepared with $0.30 \mathrm{w} / \mathrm{b}$ ratio showed higher values than specimens of $0.35 \mathrm{w} / \mathrm{b}$ ratio up to $400{ }^{\circ} \mathrm{C}$. After that, the behavior was changed in which the specimens of $0.35 \mathrm{w} / \mathrm{b}$ showed better performance than in case of specimens prepared with $0.3 \mathrm{w} / \mathrm{b}$. This could be attributed to the fact that at a low $\mathrm{w} / \mathrm{b}$ ratio $(0.30)$, the microstructure of HCP is very dense which lead to the formation of sharp cracking at elevated temperatures.

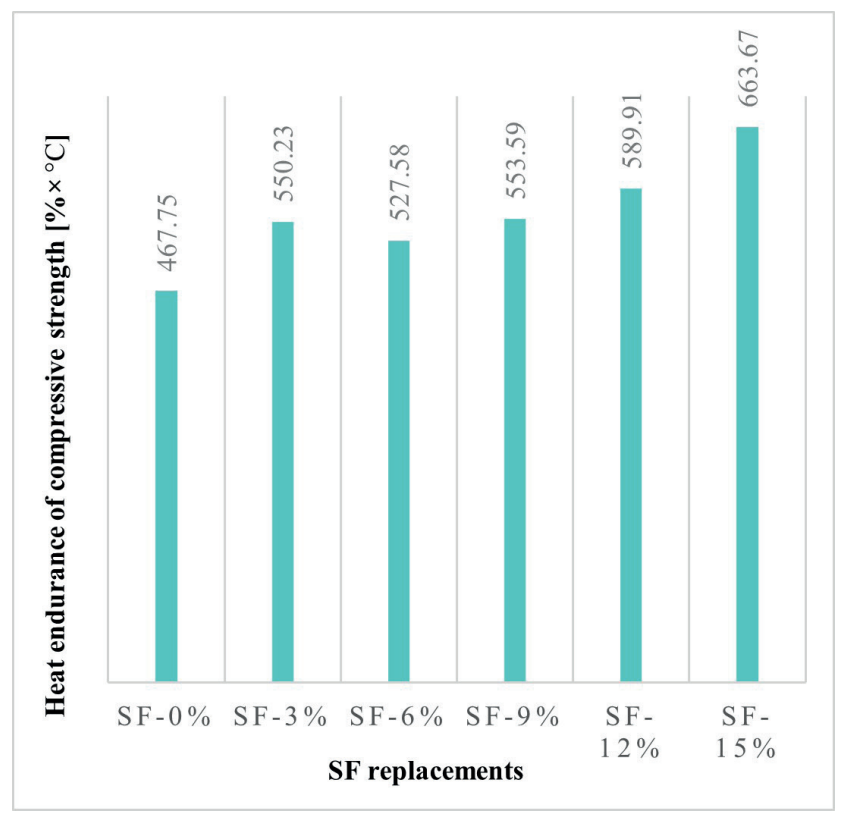

Fig. 8 Heat endurance of all $\mathrm{HCP}$ mixtures prepared with $0.40 \mathrm{w} / \mathrm{b}\left[\% \times{ }^{\circ} \mathrm{C}\right]$

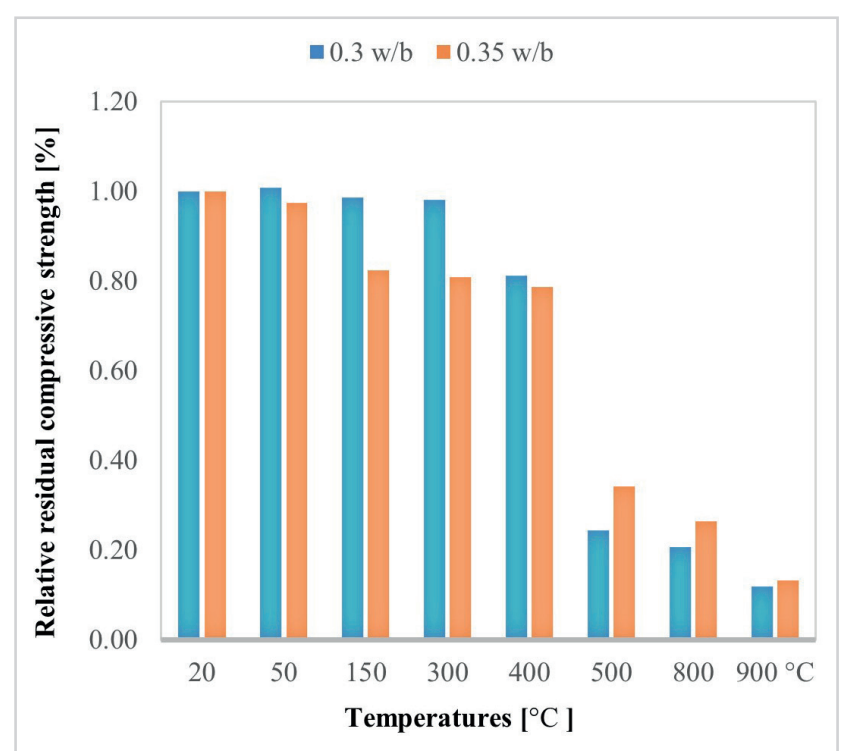

Fig. 9 Effect of w/b ratio for reference specimens (SF 0\%) at different temperatures exposures 
The increase of $\mathrm{w} / \mathrm{b}$ ratio increases the moisture content and the permeability of the HCP. The high moisture content would adversely affect the behavior of the hardened paste at elevated temperatures, whereas the high permeability of the HCP would have positive behavior. As moisture content increases, the amount of physically bounded water increases, resulting in both pore pressure and temperature gradient at elevated temperatures. Besides, many researchers have noted that decreasing moisture amount reduces spalling [35]. Regarding the current work results, to some extent, mixtures made with a high $\mathrm{w} / \mathrm{b}$ ratio, the increase of permeability was more advantageous than increasing moisture content in the HCP exposed to elevated temperature.

Based on the test results of this research, the inclusion of SF on HCP has more positive effects on the compressive strength results at elevated temperatures. The optimum mixtures of SF with any of the three $w / b$ ratios are shown in Fig. 10. Using any of the used w/b ratios, the optimum amount of the needed SF was considered and relied on mixtures that exhibited less loss in the residual compressive strength behavior. The general behavior of SF replacement was limited by the high-density microstructure, which was the prominent problem that causes cracks. The latter effect was also changed by the amount of free water that forms the porosity in the structure of HCP. Therefore, the limited use of the amount of SF varies by changing the amount of $w / b$ ratio.

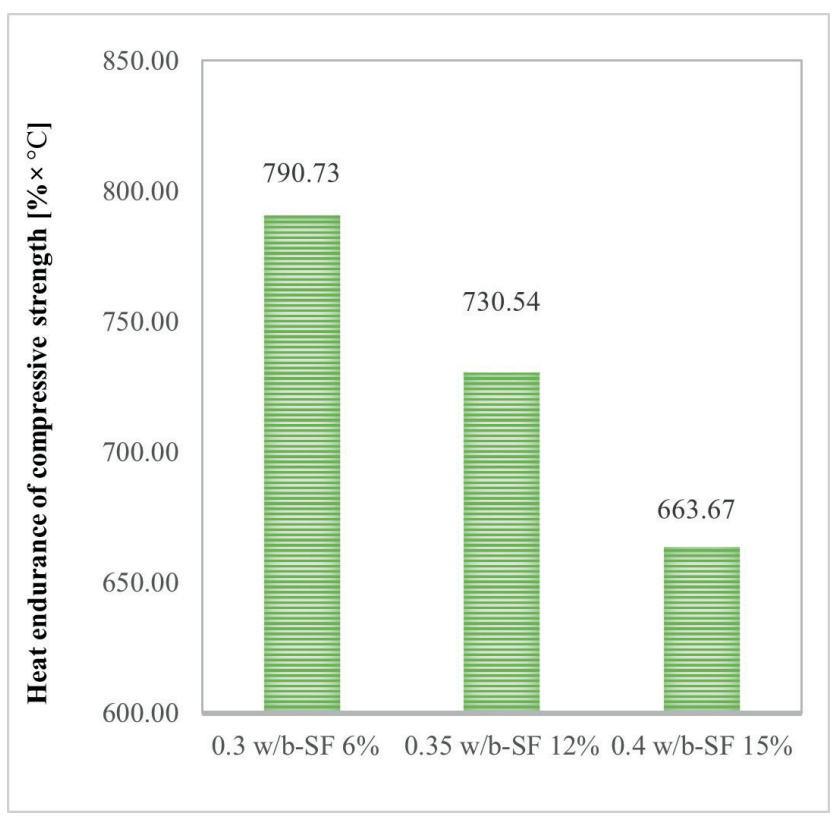

Fig. 10 Heat endurance of the HCP with optimum replacements of SF for the three $w / b$ ratio

\subsubsection{Thermogravimetric results}

The thermogravimetric test results that carried out on hardened paste samples for all of the reference mixture (SF 0\%) and the mixture containing SF (SF 6\%) are shown in Fig. 11. During the thermo-analytical test, several heat reactions occur on $\mathrm{HCP}$ between a temperature range of $20-1000{ }^{\circ} \mathrm{C}$. Most of these reactions are endothermic reactions, the test results have shown three main phases. First temperature range between $20-200{ }^{\circ} \mathrm{C}$ is basically linked to the evaporation of physically combined water, dehydration of ettringite $\left(\mathrm{C}_{3} \mathrm{~A} \cdot 3 \mathrm{CaSO} 4 \cdot \mathrm{H}_{32}\right)$, and dehydration of mono-sulfate $\left(\mathrm{C}_{3} \mathrm{~A} \cdot \mathrm{CaSO} 4 \cdot \mathrm{H}_{12}\right)$. The second range $430-540{ }^{\circ} \mathrm{C}$ is due to the decomposition of $\mathrm{Ca}(\mathrm{OH})_{2}$. The third temperature range $600-900{ }^{\circ} \mathrm{C}$ has corresponded to the decomposition of $\mathrm{C}-\mathrm{S}-\mathrm{H}$ and calcium-carbonate $\left(\mathrm{CaCO}_{3}\right)$ [36]. The amount of $\mathrm{Ca}(\mathrm{OH})_{2}$ and the amount of $\mathrm{CaCO}_{3}$ on the $\mathrm{HCP}$ are the responsible for the deterioration of the strength $[34,37]$. As shown in Fig. 11, the mixtures containing SF showed less loss of mass due to decomposition of $\mathrm{Ca}(\mathrm{OH})_{2}$ and $\mathrm{CaCO}_{3}$. Consequently, these outcomes were the main reasons for the better performance exhibited by the mixtures containing SF.

\subsubsection{Computed Tomography results}

The pores content and their distribution were determined alongside the sample using CT method, by measuring the pores with size larger than $0.01 \mathrm{~mm}$. This method provides high accuracy and could be used as an alternative method for the other standard laboratory tests [29].

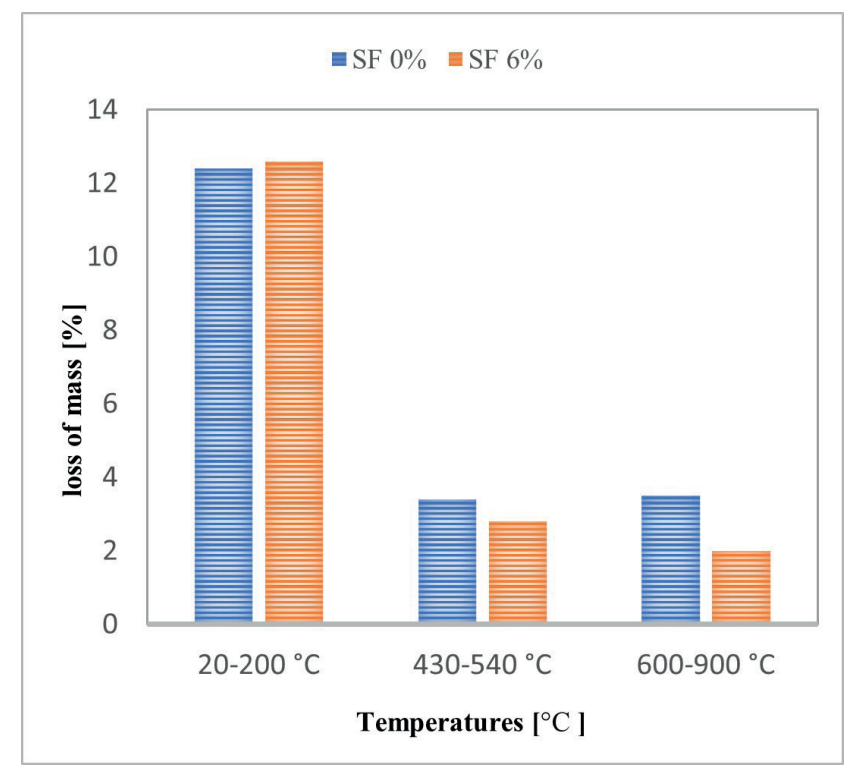

Fig. 11 TG results of the loss of mass for the reference mixture (SF 0\%) the mixture containing SF at $0.30 \mathrm{w} / \mathrm{b}$ 
Figs. 12 and 13 illustrate the obtained results of pores distribution in the $\mathrm{HCP}$ at ambient temperature $\left(20^{\circ} \mathrm{C}\right)$ for reference specimens (SF 0\%) and specimens containing SF (SF 6\%), respectively. The pattern of the results showed a decrease in the amount of the pores on the sample containing SF. This is clear where comparing the two figures (Figs. 12 and 13), confirming the packing effect added to the HCP microstructure by SF. The total pores volume was also calculated showing that the total volume of the HCP containing $6 \%$ of SF was $3.5 \%$ while the HCP without SF has a total volume of $5.93 \%$.

\subsubsection{Scanning electron microscope results}

The SEM images are presented in Fig. 14, SEM provide visual identification of HCP microstructures [38]. The images reveal the variation in the HCP microstructure before and after adding SF for specimens of ambient temperature $\left(20^{\circ} \mathrm{C}\right)$. The $\mathrm{HCP}$ without SF has abundance of $\mathrm{Ca}(\mathrm{OH})_{2}$ in hexagonal form. In contrast, the HCP

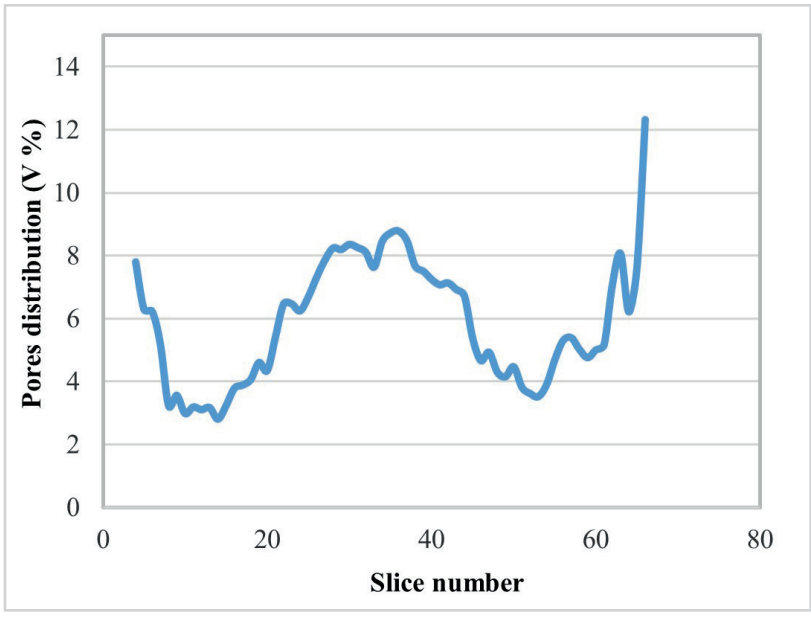

Fig. 12 The distribution of pores through the reference HCP (SF 0\%)

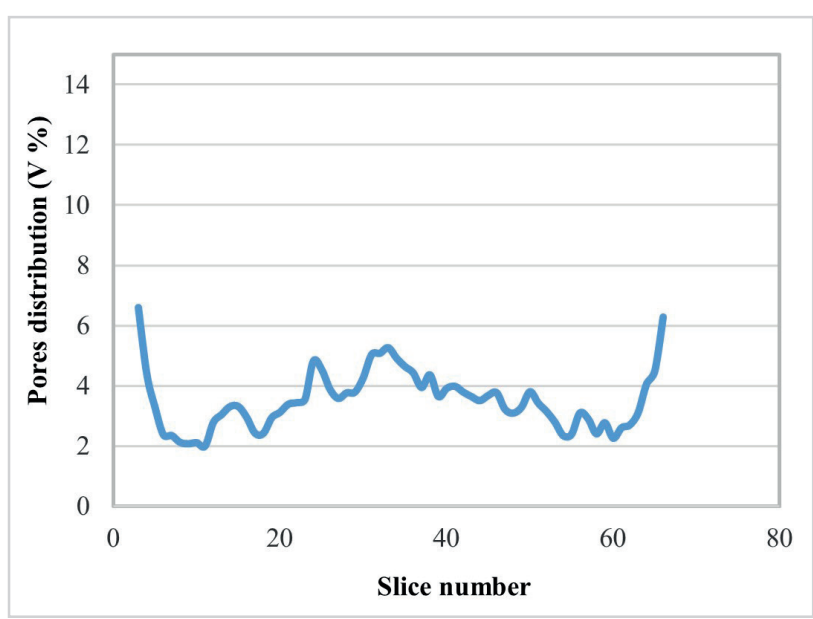

Fig. 13 The distribution of pores through the HCP containing $6 \%$ of SF (SF $0 \%)$
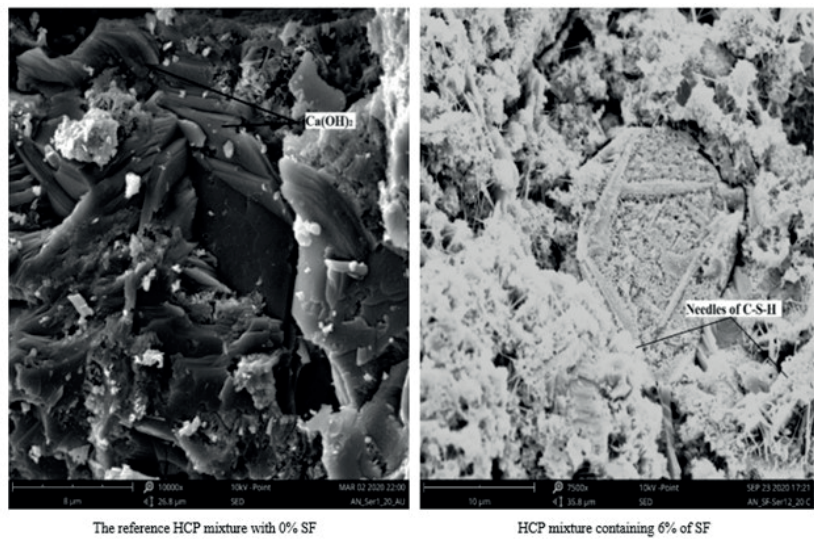

Fig. 14 The microstructure observation by SEM images for hardened paste containing $0 \%$, and $6 \%$ of SF

containing SF showed no observation for $\mathrm{Ca}(\mathrm{OH})_{2}$, and the microstructure of the sample has high amount of $\mathrm{C}-\mathrm{S}-\mathrm{H}$. These results were correspond to the pozzolanic reaction of SF with $\mathrm{Ca}(\mathrm{OH})_{2}$. As stated before, the major problem causing the deterioration of $\mathrm{HCP}$ at elevated temperatures is the decomposition of $\mathrm{Ca}(\mathrm{OH})_{2}$, where its presence in the pure HCP was about $28 \%$ of its mass [39]. For that reason, mixtures containing SF showed better performance at elevated temperatures.

\section{Conclusions}

The aim of the current experimental study is to evaluate the performance of HCP incorporated with SF after exposure to elevated temperatures. The used parameters were $\mathrm{SF}$ replacements, $\mathrm{w} / \mathrm{b}$ ratio, and temperature levels. To the best knowledge of authors, testing the effect of SF additives with short incremental replacements at elevated temperatures is not covered before in the literature. Moreover, the work presents additional measurement techniques, i.e., TG/DTG/DTA, CT, and SEM, to understand further the mechanism of the SF effect. The main findings were the following:

1. The obtained optimum replacements of SF at ambient temperature were different from the optimum replacements obtained after exposure to elevated temperatures.

2. The efficiency of SF in compressive strength at ambient temperature was higher in mixtures mixed with a high $\mathrm{w} / \mathrm{b}$ ratio than mixtures mixed with low $\mathrm{w} / \mathrm{b}$.

3. Regarding $\mathrm{w} / \mathrm{b}$ ratio 0.30 , mixtures containing $6 \%$ of SF possess the highest relative residual compressive strength after exposure to elevated temperatures and with the highest heat endurance. Results of relative residual strength values were $97 \%$ and $64 \%$ after exposure to 500 and $800{ }^{\circ} \mathrm{C}$, respectively. 
4. Regarding $\mathrm{w} / \mathrm{b}$ ratio 0.35 , mixtures containing $12 \%$ SF possesses the highest relative residual compressive strength at elevated temperatures and with the highest heat endurance. Results of relative residual strength values were $84 \%$ and $53 \%$ after exposure to 500 and $800^{\circ} \mathrm{C}$, respectively.

5. Regarding w/b ratio 0.40 , mixtures containing $15 \%$ of SF possess the highest relative residual compressive strength after exposure to elevated temperatures and with the highest heat endurance. Results of relative residual strength values were $77 \%$ and $51 \%$ after exposure to temperatures 500 and $800{ }^{\circ} \mathrm{C}$, respectively.

\section{References}

[1] ACI Committee 363 "Report on High-Strength Concrete", American Concrete Institute, Farmington Hills, MI, USA, Rep. ACI 363R-92, 1992.

[2] Cassagnabère, F., Diederich, P., Mouret, M., Escadeillas, G., Lachemi, M. "Impact of metakaolin characteristics on the rheological properties of mortar in the fresh state", Cement and Concrete Composites, 37, pp. 95-107, 2013.

https://doi.org/10.1016/j.cemconcomp.2012.12.001

[3] Lessard, S., Aitcin, P. C., Regourd, M. "Development of a Low Heat of Hydration Blended Cement, Fly Ash, Silica Fume, Slag, and Other Mineral By-Products in Concrete", In: Proceedings of the First CANMET/ACI International Conference, Montebello, QC, Canada, 1983, pp. 747-764.

[4] ACI Committee 234 "Guide for the Use of Silica Fume in Concrete", Farmington Hills, MI, USA, Rep. ACI 234R-96, 2006.

[5] Behnood, A., Ziari, H. "Effects of silica fume addition and water to cement ratio on the properties of high-strength concrete after exposure to high temperatures", Cement and Concrete Composites, 30, pp. 106-112, 2008.

https://doi.org/10.1016/j.cemconcomp.2007.06.003

[6] Abdelmelek, N., Lubloy, E. "The impact of metakaolin, silica fume and fly ash on the temperature resistance of high strength cement paste", Journal of Thermal Analysis and Calorimetry, 2021. https://doi.org/10.1007/s10973-021-10700-x

[7] Abdelmelek, N. "Influence of Supplementary Cementitious Materials on the Properties of High Strength Cement Paste at Elevated Temperatures", PhD Thesis, Budapest University of Technology and Economics, 2021. [online] Available at: https:/em.bme.hu/sites/ default/files/page/Nabil\%20Abdelmelek_Thesis_2021.pdf

[8] Cohen, M. D., Olek, J., Dolch, W. L. "Mechanism of Plastic Shrinkage Cracking in Portland Cement and Portland Cement-Silica Fume Paste and Mortar", Cement and Concrete Research, 20(1), pp. 103-119, 1990.

https://doi.org/10.1016/0008-8846(90)90121-D

[9] Wang, J., Liu, B., Xie, S., Wu, Z. "Improvement of Paste-Aggregate Interface by Adding Silica Fume", In: Proceedings of the 8th International Congress on the Chemistry of Cement, Rio de Janeiro, Brazil, 1986, pp. 460-465.
6. Thermogravimetric results confirm the positive contribution of SF on HCP at elevated temperature, showing that the mass loss obtained by the composition of $\mathrm{Ca}(\mathrm{OH})_{2}$ and $\mathrm{CaCO}_{3}$ is less in the case of specimens contain SF.

7. The quantitative analysis by CT measurement and SEM images shows the changes that occurred on the $\mathrm{HCP}$ by adding SF in the porosity and in the formed chemical compounds.

\section{Acknowledgment}

The authors acknowledge the support by the Hungarian Research Grant NVKP_16-1-0019. The authors wish to thank the "Universite 8 Mai 1945 Guelma" as well.

[10] Shannag, M. J. "High strength concrete containing natural pozzolan and silica fume", Cement and Concrete Composites, 22(6), pp. 399406, 2000 .

https://doi.org/10.1016/S0958-9465(00)00037-8

[11] Poon, C.-S., Azhar, S., Anson, M., Wong, Y.-L. "Comparison of the strength and durability performance of normal and high-strength pozzolanic concretes at elevated temperatures", Cement Concrete Research, 31, pp. 1291-1300, 2001. https://doi.org/10.1016/S0008-8846(01)00580-4

[12] Alimrani, N., Abdelmelek, N., Balázs, Gy. L., Lublóy, É. "Fire Behaviour of Concrete - Influencing Parameters", Concrete Structures, 18, pp. 30-35, 2017. [online] Available at: http://fib.bme.hu/folyoirat/ cs/cs2017.pdf

[13] Abdelmelek, N., Lublóy, É. "Improved fire resistance by using different dosages of metakaolin", In: Proceedings of the 12th Central European Congress on Concrete Engineering, Tokaj, Hungary, 2017, pp. 240-245.

[14] Phan, L. T., Carino, N. J. "Effects of test conditions and mixture proportions on behaviour of high-strength concrete exposed to high temperatures", ACI Materials Journal, 99(1), pp. 54-66, 2002.

[15] Hertz, K.D. "Danish Investigations on Silica Fume Concretes at Elevated Temperatures", ACI Materials Journal, 89(4), pp. 345-347, 1992.

https://doi.org/10.14359/9750

[16] Jahren, P. A. "Fire Resistance of High Strength/Dense Concrete With Particular Reference to the Use of Condensed Silica Fume--A Review", In: Proceedings of the 3rd International Conference on Fly Ash, Silixa Fuma, Slag and Natural Pozzolans in Concrete, Trondheim, Norway, 1989, pp. 1013-1050.

[17] Lin, W.-M., Lin, T. D., Powers-Couche, L. J. "Microstructures of fire-damaged concrete", ACI Materials Journal, 93(3), pp. 199-205, 1996.

[18] Rostásy, F. S., Weiß, R., Wiedemann, G. "Changes of pore structure of cement mortars due to temperature", Cement and Concrete Research, 10(2), pp. 157-164, 1980. https://doi.org/10.1016/0008-8846(80)90072-1 
[19] Peng, G.-F., Huang, Z.-S. "Change in microstructure of hardened cement paste subjected to elevated temperatures", Construction and Building Materials, 22(4), pp. 593-599, 2008.

https://doi.org/10.1016/j.conbuildmat.2006.11.002

[20] Heikal, M., El-Didamony, H., Sokkary, T. M., Ahmed, I. A. "Behavior of composite cement pastes containing microsilica and fly ash at elevated temperature", Construction and Building Materials, 38, pp. 1180-1190, 2013.

https://doi.org/10.1016/j.conbuildmat.2012.09.069

[21] Gómez-Zamorano, L. Y., Escalante-García, J. I. "Effect of curing temperature on the nonevaporable water in portland cement blended with geothermal silica waste", Cement and Concrete Composites, 32(8), pp. 603-610, 2010.

https://doi.org/10.1016/j.cemconcomp.2010.07.004

[22] HIS "MSZ EN 196-2 Methods of testing cement. Part 2: Chemical analysis of cement", Hungarian Standards Institution, Budapest, Hungary, 2013.

[23] CEN "EN 197-1 Cement - Part 1: Composition, specifications and conformity criteria for common cements", European Committee for Standardization, Brussels, Belgium, 2000.

[24] CEN "EN 1008:2002 Mixing water for concrete-Specification for sampling, testing and assessing the suitability of water, including water recovered from processes in the concrete industry, as mixing water for concrete", European Committee for Standardization, Brussels, Belgium, 2002.

[25] CEN "EN 196-1:2016 Methods of testing cement- Part 1:. Determination of strength", European Committee for Standardization, Brussels, Belgium, 2016.

[26] The Concrete Society "TR 41 Microsilica in concrete", The Concrete Society, Camberley, UK, Rep. TR 41, 1993.

[27] DIN "DIN EN 459-2 Building Lime - Part 2: Test Methods", German Institute for Standardization, Berlin, Germany, 2010.

[28] ISO "ISO-834 Fire-resistance tests - Elements of building construction", International Organization for Standardization, Geneva, Switzerland, 1975.

[29] Lublóy, É., Ambrus, D., Kapitány, K., Barsi, Á. "Air Void Distribution of Asphalts Determined by Computed Tomography", Periodica Polytechnica Civil Engineering, 59(4), pp. 503-510, 2015. https://doi.org/10.3311/PPci.7608

[30] Lublóy, É., Kapitány, K., Balázs, G. L., Földes, T., Hlavicka, V., Hlavicka-Laczák, L. "CT and laboratory test of the wall panels after fire load", Construction and Building Materials, 211, pp. 1105-1116, 2019.

https://doi.org/10.1016/j.conbuildmat.2019.03.148
[31] Tam, V.W. Y., Butera, A., Le, K. N. "Microstructure and chemical properties for $\mathrm{CO}_{2}$ concrete", Construction and Building Materials, 262, Article number: 120584, 2020.

https://doi.org/10.1016/j.conbuildmat.2020.120584

[32] RILEM Technical Committees 129-MHT "Test Methods for mechanical properties of concrete at high temperatures, Part 1: Introduction, Part 2: Stress-strain relation, Part 3: Compressive strength for service and accident conditions", Materials and Structures, 28(181), pp. 410-414, 1995.

[33] Fehérvári, S., Nehme, S. G. "Effect of Concrete Components on the Temperature Endurance of Tunnel Linings", PhD Thesis, Budapest University of Technology and Economics, 2009.

[34] Lublóy, É., Kopecskó, K., Balázs, G. L., Szilágyi, I. M., Madarász, J. "Improved fire resistance by using slag cements", Journal of Thermal Analysis and Calorimetry, 125(1), pp. 271-279, 2016. https://doi.org/10.1007/s10973-016-5392-z

[35] Chan, S. Y. N., Peng, G.-F., Anson, M. "Fire behaviour of high-performance concrete made with silica fume at various moisture contents", ACI Materials Journal, 96(3), pp. 405-411, 1999. https://doi.org/10.14359/640

[36] Abdelmelek, N., Lubloy, E. "Flexural strength of silica fume, fly ash, and metakaolin of hardened cement paste after exposure to elevated temperatures", Journal of Thermal Analysis and Calorimetry, 2021. https://doi.org/10.1007/s10973-021-11035-3

[37] Balázs, G .L., Kopecskó, K., Alimrani, N., Abdelmelek, N., Lublóy, É. "Fire Resistance of Concretes with Blended Cements", In: Hordijk, D. A., Luković, M. (eds.) High Tech Concrete: Where Technology and Engineering Meet, Springer, Cham, Switzerland, 2018, pp. 1420-1427. https://doi.org/10.1007/978-3-319-59471-2_163

[38] Abdelmelek, N., Alimrani, N. S., Krelias, N., Lubloy, E. "Effect of Elevated Temperatures on Microstructure of High Strength Concrete Based-Metakaolin", Journal of King Saud University - Engineering Sciences, 2021. (Accepted for publication August 2021) (in press) https://doi.org/10.1016/j.jksues.2021.08.001

[39] Abdelmelek, N., Lubloy, E. "Evaluation of the mechanical properties of high-strength cement paste at elevated temperatures using metakaolin", Journal of Thermal Analysis and Calorimetry, 145, 2020.

https://doi.org/10.1007/s10973-020-09992-2 